\title{
Interior of Pracimayasa as the Cultural Inheritance of Solo City in Creative Industry
}

\author{
Sunarmi $^{1}$, Bani Sudardi ${ }^{2}$, Pande Made Sukerta ${ }^{3}$, Titis Srimuda Pitana ${ }^{4}$ \\ ${ }^{1}$ Doctorate Program of Cultural Studies, Sebelas Maret University, Indonesia \\ ${ }^{2}$ Postgraduate Program of Cultural Studies, Sebelas Maret University, Indonesia \\ ${ }^{3}$ Indonesian Art Institute of Surakarta, Indonesia \\ ${ }^{4}$ Architecture Study Program, Sebelas Maret University, Indonesia \\ sunarmi.interior67@gmail.com (Sunarmi), banisudardi@yahoo.co.id (Bani Sudardi), pandemadesukerta@gmail.com (Pande Made Suk- \\ erta), titis_pitana@yahoo.com (Titis Srimuda Pitana)
}

\begin{abstract}
Interior of Pracimayasa as the cultural inheritance of Solo city in creative industry is a cultural studies research. The problem of research was how the preservation of Pracimayasa's interior as the cultural pledge building in creative industry. The interior of Pracimayasa as the noble family's residence always represents Javanese ethic and etiquette in vis-à-vis to modern life. This research employed critical deconstruction theory supported with visual communication semiotic theory with hermeneutic approach. The study was expected to give the opportunity of developing creativity in interpreting text, the interior of cultural pledge building. Data collection was carried out using observation, interview, document study, and library study. Data validation was conducted using data triangulation. The result of research showed that (1) rationality in modernism resulted in new awareness that interior of Pracimayasa as the cultural heritage became tourist package in dinner or lunch tour in global era interpreted as the recognition through deconstruction process, thereby generating new interpretation and understanding on the interior of Pracimayasa, (2) the characteristics of Pracimayasa's interior should be the source of interior designing idea in global era in realizing the concept of interior esthetic balanced and harmonious with its cosmos to achieve the harmonization of civilization in global era.
\end{abstract}

Keywords rationality, creative industry, interior characteristics of Pracimayasa, harmony

\section{Introduction}

Pracimayasa building constituting a cultural pledge building is a residence of Mangkunegaran royal family, with tangible and intangible cultural heritage [1]. Pracimayasa building as the cultural pledge object should be protected corresponding to Republic of Indonesia's Law No. 11 of 2010 about Cultural Pledge. As the cultural pledge, Pura Mangkunegaran and the cultural activities within it are preserved. On the other hand, the release of Republic of Indonesia's Law Number 10 of 2009 about Tourism and Local Regulation of Central Java Province Number 10 of 2012 about the Tourism Development Master Plan of Central Java Province in 2012-2027 put Mangkunegaran onto dilemmatic position.

Tourism development is considered as having potency in economic reinforcement, often called creative economy. Tourism and Creative Economy Minister explains that creative economy is the fourth wave of economic development following agricultural, industry and information technology [2]. Creative economy is how to create added-value of knowledge base including existing cultural heritage and technology. It means that Pracimayasa building located in cultural pledge area becomes an integral part of tourism development. In the attempt of developing tourism, Mangkunegaran includes Pracimayasa building as the family's residence sold in dinner or lunch tour package. The process of converting an object formerly not having monetary value into the one with monetary value is called commodification. Commodification is defined as the process of making non-commodity object to commodity one [3].

This phenomenon generates a question "how is commodification of Pracimayasa building viewed from conservation and creative aspects. The interior of Pracimayasa, as the royal family's residence, is a private building. Meanwhile, in commodification domain, something produced is oriented to sale value. Barker [4], explains that commodification is a process associated with capitalism in which object, quality and signs are converted into commodity, something intended to be sold in the market.

\section{Research Methodology}

This research attempts to explain the commodification of Pracimayasa Building in Mangkunegaran. Pracimayasa Building, as cultural heritage building formerly having private function, now has public function in the context of tourism. This research is directed to conceive the meaning of commodification built by agents as a relation consisting of: 
producer, distributor, and consumer of commodity. Bungin [5], explains that the research attempts to look for meaning, so that the data in the form of description of narrative text, words, expressions, opinion, and ideas were collected from many sources corresponding to the technique of collecting data used. Thus, the analysis model employed was a qualitative one.

This research was positioned in critical deconstruction system, using Derrida's critical deconstruction and Umberto Eco's semiotic theories. Corresponding to the type of research, opened to cultural study research, the eclectic theory used was obtained through process. The process was conducted pragmatically, in which the author uses theory corresponding to the characteristics of object encountered [6]. Techniques of collecting data used were observation and interview in addition to document and library studies. Data derived from information related directly to the Pracimayasa building commodification event with various supporting documents. The empirical data obtained from the field was necessary to understand the object of study comprehensively, because a research is basically and individual's attempt of approaching, understanding, elaborating, and explaining the phenomenon related to certain object [7]. The written data derived from data source including book, journal, document, previous studies relevant to custom and etiquette in Mangkunegaran.

\section{Result and Discussion}

\section{Pracimayasa building is cultural pledge building}

in Pura Mangkunegaran Surakarta area now becoming the dinner or lunch tour package. Commodification is defined as the process of making non-commodity object to commodity one [8]. Fairclough [9] (1995: 207), explains that commodification is a process in which social domains and institutions focus their attention on not only producing commodity in a narrow definition of economy concerning the products to be sold, but on how to organize and conceptualize them from production, distribution, and commodity consumption. Commodification is to make something a commodity, directly and deliberately, consciously and maturely. Supriyanto suggested that dinner or lunch tour is a tour package selling a circumstance of royal guest welcoming, in which the tourists were treated just like the royal guest [10]. Considering such the statement, commodification of Pracimayasa building has been conducted with mature consideration converting Pracimayasa building as well as its meaning with no monetary value into the one with monetary value.

The meaning of royal family residence is constructed and revived to make imitation or simulation of royal guest wel- coming sold in dinner or lunch tourism package. The term of simulation or simulacrum in this study borrows Baudrillard's opinion related to the appearance production model in consumer community no longer related to duplication of "being" or substance of something duplicated, but the creation of real models without origin or reality, hyper real [11]. The reference of duplication is no longer a reality, but what is unreal is fantasy. Fantasy is simulated into as if something real.

The tourists coming to Mangkunegaran are welcomed just like the royal guest. Pracimayasa building is activated to be means of Mangkunegaran palace's activities in receiving the royal guest. Custom and procedure of welcoming royal guest are constructed through a variety of signs without reference. The image of palace is not related to reality at all, the image of royal guest welcoming is the pure simulacrum, because it is actually a simulacrum of royal guest welcoming only, there is only a simulation making Pracimayasa building the medium just like royal family's residence. A series of activities is organized based on idea of establishing a royal guest welcoming circumstance. Pengageng and relative have never been present to welcome the tourists, the royal guest is only pseudo because the guest is a tourist, art presentation and banquette is not intended to the royal guest but to the tourist, all of which are simulation of royal guest welcoming conducted by the tour management in Mangkunegaran. Pracimayasa, building, custom and traditional etiquette of Mangkunegaran are the media of building brand. Interior circumstance is built through simulacrum of royal guest welcoming to build the royal guest hyperreality. Mangkunegaran as the owner and the manager all at once produces a sign building a royal guest welcoming circumstance to be captured and enjoyed by dinner or lunch tourists. As suggested by Umberto Eco, the semiotic work mechanism in communication, the manager of Pracimayasa building becoming the author is called interpretant of first sign to be built (Pracimayasa building), that in turn refers to object (meaning of Pracimayasa building), and tourist becomes representamen. Thus, a sign or representamen has triadic relation with its interpretant and object. Considering the field observation, the process of producing simulacrum of the Mangkunegaran Palace family residence interior for welcoming the royal guest in semiotic process leads to the 
shift of space's function in Pura Mangkunegaran Surakarta not only Pracimayasa building, from the Pura's yard converted into parking area, Topengan into vehicle transit place, Pendopo into the art performance stage, Paringgiran and Dalem Ageng into tourist circulation place, and Pracimayasa ward into photo booth. The residence in the concept of traditional house is organized based on hierarchy, ethic reflection of Javanese etiquette, has shifted into the place of building memory in social media practice for the tourists.

The elaboration above shows that the attempt of Pracimayasa building in dinner or lunch tourist package is based on the spirit of conservation by means of reviving the function of every main room of Pracimayasa building as the place where royal guest welcoming tradition lives in Mangkunegaran, but finally has changed the meaning of Pracimayasa building. When facing the change, the meaning of Pracimayasa building in Mangkunegaran is the object made the commodity in a tourism industry. The commodity builds on reengineering action in individual relation and production relation about the interior simulacrum of royal guest welcoming place. Individual relation is fluid, not related to each other individual. Meanwhile, in production relation, it is commodified sustainably and is a unity. No interaction between both of them but compelled integration of a need system to production system. The consumption object is a particular articulation of a series of expression, the presence of which precedes commodity. In this system, it can be seen that an individual is constructing his own idiom until he/she loses the correct sentence, until one is in quarrel with another and competes for influence. It is, of course, a classification system rather than a language. Such the need is created by consumption object because object acts as the category of object determining the human category arbitrarily. The private meaning of Pracimayasa building is that it becomes a prestigious place for tourist, as a commodity included into cyber world by tourists and travel agent through viral social media. This phenomenon will exert ongoing impact due to social media and technology's influence.

As Adian states [12], the social media and technology advance indirectly leads to the creation of consumer community, and then the object signs status social and replaces any social hierarchic difference existing. An introduction of universal code informs the community that those that can obtain dinner and lunch banquette opportunity as the guest of Mangkunegaran Palace are put into Pracimayasa along with various facilities have prestigious and special status; therefore, not everyone can get it. City tourism led Mangkunegaran to take action to commodify Pracimayasa building into the space of creating consumptive community, so that the consumption in this view can determine an individual's social status. In capitalist system, human relationship has been transformed into object relation controlled by certain code or sign [13]. The difference of status is defined as the difference of sign consumption, so that the wealth is measured by the number of sign consumed. Consuming or accessing the tourism in Pracimayasa building of Pura Mangkunegaran symbolizes the presence of status in certain social group.

Commodification of Pracimayasa building in Mangkunegaran Surakarta in dinner or lunch tour package is analogized as the screen or network converting Pracimayasa private space into consumption public one through the royal guest welcoming simulacrum. The stage of creating simulacrum in the commodification of Pracimayasa building in Mangkunegaran Surakarta of course contains a variety of dramatization conducted through a plot full of dramatic action. Generally, dramatization is controlled by the production house, in this case the tour/travel agent in cooperation with Mangkunegaran Tourism Service under Mondropuro's control, as the one responsible for Pracimayasa building as the asset in Mangkunegaran. Finally, it is impossible to distinguish the real from the spectacle only so that there is no reality but hyperreality.

The effect of simulacrum of royal guest welcoming location interior occurs due to the presence of community's trust in the reality actually unreal. This duping over reality can result in a cultural pattern easily imitating what seen as a reality in the media of promoting tourism realized into the event of welcoming the Royal Guest in Mangkunegaran. Therefore, such the commodification can make Mangkunegaran patterned to be consumptive society articulated as the community composed of and supported by consumption, making consumption the center of life activity 
with the wish to keep consuming [14]. Thus, commodification over the Mangkunegaran-owned Pracimayasa building develops not only as the need with exchange value and usefulness.

It is confirmed by Derrida that has deconstructed logocentrism. In the phenomenon of Pracimayasa building commodification, modernization era seems to have resulted in deconstruction over Pracimayasa building. The deconstruction of Pracimayasa's building is conducted in the frame of conservation, so that the private meaning of Pracimayasa is not singular, but it occurs when Pracimayasa building is encountered by tourism organizer, in which the private signs become the ones interpreted freely and automatically generating new meaning as the sign with sale value through the simulacrum of royal guest welcoming.

In the stage of sign consumption, for the tourists, the private meaning shifts to the profitable or prestigious place. As suggested by Umberto Eco, in understanding sign, a series of code has been constructed to represent content, but in communication process, text is often interpreted as in contradiction with the code background intended by the author due to semiotic process. It occurs in the creative process of making Pracimayasa interior the place to welcome the royal guest, in the attempt of reviving the traditional custom and etiquette of welcoming the royal guest as one of Javanese culture' exaltedness. Finally, the interior of Pracimayasa is conceived, by tourism, as the use of space as prestigious tour destination, as the photo booth to fill in the social media in order to confirm the consumerism culture.

\section{Conclusion}

Considering the elaboration in the discussion above, it can be stated that rationality in modernism result in new awareness that the interior of Pracimayasa, as cultural inheritance, becomes the tour package in dinner and lunch tour in global era interpreted as the recognition through deconstruction process, thereby generating new interpreta- tion and understanding on the interior of Pracimayasa as the practical place in consumerism.

In creative industry domain, this measure can evidently contribute to economic development, but in conservation domain it has faded the meaning of Pracimayasa building as the residence of royal family reflecting on Javanese ethic and etiquette living within it. Therefore, in order to contribute to the creation of nation's cultural character, the characteristics of Pracimayasa interior should be the source of interior designing idea in global era in realizing the aesthetic concept of interior that is balanced and harmonious with its cosmos to achieve the harmonization of civilization in global era.

\section{REFERENCES}

[1] Sunarmi. at all. 2016. "Modernity Pressure Over Traditionalism in Tthe Commodification Oof Praci-mayasa Building Iin Pura Mangkunegaran Surakarta”. in Canadian International Journal of Social Science and Education - Canadian Research Center for Humanities and Science, Vol 9, Oktober 2016/209-219/ ISSN 2356-874X.

[2] Sunarmi, at all. 2016. "The Fall of Mangkunegaran 's Political and Economic Authorities". JESOC Journal Oof Education and Social Science (JESOC) Vol.5, Issue 2/Ockt-2016/Hal, pp.:181-186/ISSN2289-9855. (ISSN 2289-1552).

[3] [3] Piliang, Yasraf Amir. Semiotika dan Hipersemiotika. Kode, Gaya dan Matinya Makna. Bandung: Ma-tahari. 2012, 17.

[4] [4] Barker, Chris. Cultural Studies Teori dan Praktek (terjemahan: Tim Kunci Culture Studies Centre). Yogyakarta: PT. Benteng Pustaka. 2005: 517.

[5] [5] Bungin, Burhan. Analisis Data Penelitian Kualitatif: Pemahaman Filosofis dan Metodologis ke Arah Penguasaan Model Aplikasi. Ja-karta: PT Raja Grafindo Persada. 2003

[6] [6] Ratna, Kutha. Sastra dan Cultural Studies-: -Representasi Fiksi dan Fakta. Yogyakarta: Pustaka Pelajar. 2010.

[7] [7] Kleden, Ignas. Sikap Ilmiah dan Kritis Kebudayaan. Jakarta: LP3ES 1987.

[8] [8] Piliang, Yasraf Amir. Semiotika dan Hipersemiotika. Kode, Gaya dan Matinya Makna. Bandung: Ma-tahari. 2012, 17.

[9] [9] Fairclough, N. Discourse and Social Change. Chambridge: Polity Press. 1995.

[10] [10] Supriyanto, He is a Pengageng in Mandrapura office responable for taking care of all Mangkunegaran's assets (In-terview, March 5, 2015).

[11] [11] Piliang, Yasraf Amir. Tafsir Cultural Studies Atas Matinya Mak-na.Semiotika dan Hipersemioti-ka-Kode, Gaya \&Matinya Makna Edisi 4. Bandung: Jalasutra. Ma-tahari. 2003-2012.

[12] [12] Adian, Doni Garhal. "Menabur Kuasa Menuai Wacana". Majalah Basis. No. 01-02 Tahun ke 51 Jan-uari - Pebruari 2002, Hal 42-49.

[13] [13] Ritzer, George., Piliang, Yasraf Amir. Semiotika dan Hipersemioti-ka-Kode, Gaya \&Matinya Makna Edisi 4. 
Bandung: Matahari. 2012: 143-144. Teori Sosial Postmodern. Yogyakarta: Kreasi Wacana. 2003.

[14] [14] Lechte, John. Fifty Key Contempo-rary Thinkers from Structuralism to Postmodernity. London: Routledge. 2001. 